\title{
L-Tyrosine as an Eco-Friendly and Efficient Catalyst for Knoevenagel Condensation of Arylaldehydes with Meldrum's Acid in Solvent-Free Condition under Grindstone Method
}

\author{
G. Thirupathi, M. Venkatanarayana, P. K. Dubey, and Y. Bharathi Kumari \\ Department of Chemistry, College of Engineering, Jawaharlal Nehru Technological University Hyderabad, \\ Kukatpally, Hyderabad 500085, India \\ Correspondence should be addressed to G. Thirupathi, thirupathigjntuh@gmail.com
}

Received 8 September 2012; Revised 18 October 2012; Accepted 20 October 2012

Academic Editor: Ashraf Aly Shehata

Copyright ( $) 2012$ G. Thirupathi et al. This is an open access article distributed under the Creative Commons Attribution License, which permits unrestricted use, distribution, and reproduction in any medium, provided the original work is properly cited.

We investigate L-Tyrosine as an efficient catalyst for the Knoevenagel condensation of arylaldehydes with meldrum's acid containing cyclic active methylene group in solvent-free condition under grindstone method at room temperature to produce substituted5-benzylidene-2,2-dimethyl-[1,3] dioxane-4,6-diones $\mathbf{3}(\mathbf{a}-\mathbf{j})$.

\section{Introduction}

Toda introduced a method called the grindstone method $[1,2]$. In this method, solids are grounded together using a pestle and mortar to get the products. These reactions are more efficient selective than those carried out in the corresponding solutions.

Developing green chemical methods is one of the most important purposes of organic synthesis. Organic synthesis in the absence of solvent is a powerful tool for the generation of structurally different molecules whose special selectivity arises great interest. Moreover, solvent-free reactions are faster, taking just a few minutes. This aspect is coupled with the lowering of the total costs of running a reaction without solvent and specially designed equipment, which could become a very impressive factor in industry.

Carbon-carbon bond formation reaction is the most important reaction in organic synthesis [3-6]. The Knoevenagel condensation is one such reaction which facilitates $\mathrm{C}-\mathrm{C}$ double-bond formation and has been widely used in synthesis of alkenes of biological significance [7-11]. These reactions are usually catalyzed by bases [12-17] such as primary and secondary amines and their corresponding ammonium salts; Lewis acids [18-20], zeolite [21-23], and ionic liquids [24-27] have also been added to the existing list of substances that assisted Knoevenagel condensation in organic synthesis.

Knoevenagel condensation of meldrum's acid and aldehydes gives rise to substrates for variety of reactions [28]. They are used in cycloaddition reactions [29], 1,4-conjugate addition reactions and preparation of mono alkyl meldrum's acid derivatives [30], and preparation of deuterated carboxylic acid derivatives [31]. These derivatives are also used in the preparation of ketenes by $\alpha, \beta$-pyrolysis [32], which are then used for preparation of different compounds such as cyclobutadiene derivatives [33], $\alpha, \beta$-unsaturated esters [34], and $\alpha, \beta$-unsaturated amides $[35,36]$.

Tyrosine is known to be an efficient, bifunctional, zwitterionic, and ecofriendly catalyst. It is available in both the enantiomeric, (S)-Tyrosine and (R)-Tyrosine, forms. The two functional groups of tyrosine enable it to act both as an acid as well as a base catalyst in chemical condensation reactions.

In this paper, we highlight our findings on the L-tyrosine catalyzed condensation of arylaldehydes with meldrum's acid containing cyclic active methylene group in solvent-free condition under grindstone method at room temperature to produce substituted -5-benzylidene-2,2-dimethyl-[1,3] dioxane-4,6-diones in solvent-free condition under grindstone method at room temperature. 
TABle 1: Synthesis of substituted -5-benzylidene-2,2-dimethyl-[1,3]dioxane-4,6-dione with Knoevenagel condensation in solvent-free condition under grindstone method at room temperature.

\begin{tabular}{lcccccc}
\hline S. Number & $\mathrm{R}$ & Condition & Time $(\mathrm{min})$ & Yield $(\%)$ & $\mathrm{mp}\left({ }^{\circ} \mathrm{C}\right)$ & $\left(\right.$ Lit.mp., 28, 37, 38, 39 \& 40) $\left({ }^{\circ} \mathrm{C}\right)$ \\
\hline $\mathrm{a}$ & $\mathrm{C}_{6} \mathrm{H}_{5}$ & r.t. & 7 & 93 & $84-85$ & $85-86$ \\
$\mathrm{~b}$ & $4-\mathrm{CH}_{3}-\mathrm{C}_{6} \mathrm{H}_{4}$ & r.t. & 15 & 91 & $117-118$ & $116-118$ \\
$\mathrm{c}$ & $4-\mathrm{OCH}_{3}-\mathrm{C}_{6} \mathrm{H}_{4}$ & r.t. & 15 & 91 & $124-125$ & $126-127$ \\
$\mathrm{~d}$ & $\mathrm{p}-\left(\mathrm{Me}_{2} \mathrm{~N}\right)-\mathrm{C}_{6} \mathrm{H}_{4}$ & r.t. & 14 & 92 & $163-165$ & $162-164$ \\
$\mathrm{e}$ & $\mathrm{p}-(\mathrm{OH})-\mathrm{C}_{6} \mathrm{H}_{4}$ & r.t. & 13 & 92 & $195-196$ & $192-194$ \\
$\mathrm{f}$ & $\mathrm{p}-(\mathrm{Cl})-\mathrm{C}_{6} \mathrm{H}_{4}$ & r.t. & 8 & 94 & $157-158$ & $158-160$ \\
$\mathrm{~g}$ & $\mathrm{p}-\left(\mathrm{NO}_{2}\right)-\mathrm{C}_{6} \mathrm{H}_{4}$ & r.t. & 7 & 94 & $127-128$ & $217-129$ \\
$\mathrm{~h}$ & $\mathrm{O}-\left(\mathrm{NO} \mathrm{O}_{2}\right)-\mathrm{C}_{6} \mathrm{H}_{4}$ & r.t. & 8 & 93 & $118-120$ & $119-120$ \\
$\mathrm{i}$ & $\mathrm{O}-(\mathrm{Cl})-\mathrm{C}_{6} \mathrm{H}_{4}$ & r.t. & 8 & 93 & $133-135$ & $133-134$ \\
$\mathrm{j}$ & $\mathrm{M}-(\mathrm{OH})-\mathrm{C}_{6} \mathrm{H}_{4}$ & r.t. & 13 & 92 & $173-174$ & $175-176$ \\
\hline
\end{tabular}

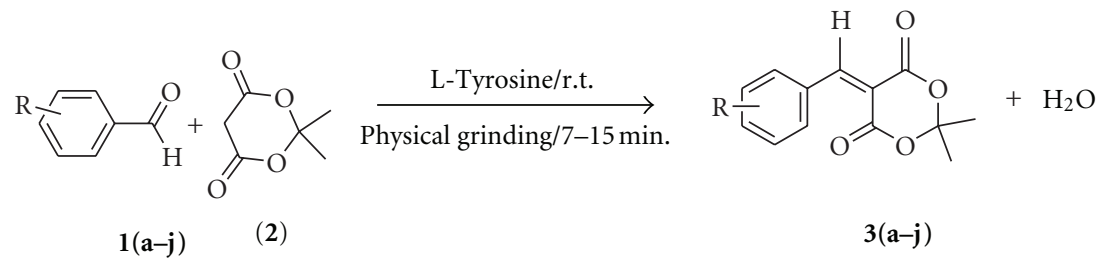

Scheme 1: Knoevenagel condensation of arylaldehydes with meldrum's acid in the presence of L-tyrosine in solvent-free condition under grindstone method. (a) $\mathrm{R}=\mathrm{C}_{6} \mathrm{H}_{5}$, (b) $\mathrm{R}=\mathrm{CH}_{3}-\mathrm{C}_{6} \mathrm{H}_{4}$, (c) $\mathrm{R}=\mathrm{OCH}_{3}-\mathrm{C}_{6} \mathrm{H}_{4}$, (d) $\mathrm{P}-\left(\mathrm{Me}_{2} \mathrm{~N}\right)-\mathrm{C}_{6} \mathrm{H}_{4}$, (e) $\mathrm{P}-(\mathrm{OH})-\mathrm{C}_{6} \mathrm{H}_{4}$, (f) $\mathrm{P}-(\mathrm{Cl})-\mathrm{C}_{6} \mathrm{H}_{4}$, (g) $\mathrm{P}-\left(\mathrm{NO}_{2}\right)-\mathrm{C}_{6} \mathrm{H}_{4},(\mathrm{~h}) \mathrm{O}-\left(\mathrm{NO}_{2}\right)-\mathrm{C}_{6} \mathrm{H}_{4}$, (i) $\mathrm{O}-(\mathrm{Cl})-\mathrm{C}_{6} \mathrm{H}_{4}$, and (j) $\mathrm{M}-(\mathrm{OH})-\mathrm{C}_{6} \mathrm{H}_{4}$.

\section{Results and Discussion}

Arylaldehydes $\mathbf{1}(\mathbf{a}-\mathbf{j})$ were subjected to condensation with meldrum's acid containing cyclic active methylene group in the presence L-tyrosine in solvent-free condition under grindstone method at room temperature for $7-15 \mathrm{~min}$. resulting in the formation of substituted -5-benzylidene-2,2dimethyl-[1,3] dioxane-4,6-diones $\mathbf{3}(\mathbf{a}-\mathbf{j})$ in $\mathbf{9 1 - 9 4 \%}$ yields (Table 1 and Scheme 1). This method is very convenient for the preparation of large amount of substituted -5-benzylidene-2,2-dimethyl-[1,3] dioxane-4,6-diones with high yields in less time. L-Tyrosine as an ecofriendly and efficient catalyst to induce the reaction.

In the absence of L-tyrosine, the reaction does not proceed the reactants in the solvent-free condition under grindstone method at room temperature for $4 \mathrm{~h}$. The use of L-tyrosine as a catalyst helps to avoid the use of environmentally unfavourable organic solvents as reaction medium.

The above reactions of $\mathbf{1}(\mathbf{a}-\mathbf{j})$ with meldrum's acid were attempted in the presence of various amino acids like valine, glycine, alanine, and Lysine in the solvent-free condition under grindstone method at room temperature for $5 \mathrm{~h}$. but there was not much progress in the reactions as seen by TLC examination of crude reaction mixtures. In the presence of phenyl alanine and L-tryptophan in the solvent-free condition under grindstone method at room temperature, there was a little bit of progress, but the reaction was not completed for $5 \mathrm{hrs}$.

The above reactions of arylaldehydes $\mathbf{1}(\mathbf{a}-\mathbf{j})$ with meldrum's acid containing cyclic active methylene group were attempted in the presence of L-proline low yield which was obtained for $1 \mathrm{~h}$ in the solvent-free condition under the grindstone method at room temperature.

The above reactions of arylaldehydes $\mathbf{1}(\mathbf{a}-\mathbf{j})$ with meldrum's acid containing cyclic active methylene group were attempted in the presence of various bases like $\mathrm{NaOH}, \mathrm{KOH}$ which were too strong bases to result in more byproducts. Low yield was obtained and $3 \mathrm{~h}$ reaction time is needed using $\mathrm{K}_{2} \mathrm{CO}_{3}$, ammonium acetate, piperidine, and triethylamine as catalyst for condensation of arylaldehydes $\mathbf{1}(\mathbf{a}-\mathbf{j})$ with meldrum's acids containing cyclic active methylene group (2) in the solvent-free condition under the grindstone method at room temperature.

From Table 1, it was shown that the condensation of arylaldehydes with electron withdrawing group such as $-\mathrm{NO}_{2}$ and $-\mathrm{Cl}$ at paraposition with meldrum's acid containing cyclic active methylene compounds can be carried out in relatively shorter time and higher yield than with electron donating group such as $-\mathrm{OH},-\mathrm{OCH}_{3}$, and $\mathrm{N}, \mathrm{N}$-dimethyl arylaldehydes in the solvent-free condition under the grindstone method at room temperature.

A plausible mechanism for the formation of 3 from $\mathbf{1}$ and 2 in the presence of L-tyrosine as catalyst is shown in Scheme 2. The reaction mechanism is supported by the literature reference [37].

In the mechanism shown in Scheme 2, L-tyrosine, in its zwitterionic form (Xb), abstracts a proton from meldrum's acid containing cyclic active methylene group (2) forming the carbanion of meldrum's acid $\left(2^{\mathrm{I}}\right)$ which then attacks the protonated arylaldehydes $\left(\mathbf{1}^{\mathrm{I}}\right)$ forming the corresponding intermediate $\left(\mathbf{1}^{\mathrm{II}}\right)$ that loses water to form the end product 3 . 
<smiles>[X]c1ccc(CC(N)C(=O)O)cc1</smiles>

$\mathrm{Xa}$<smiles>[NH3+][C@@H](Cc1ccc(O)cc1)C(=O)[O-]</smiles>

$\mathrm{Xb}$<smiles>[NH3+][C@H](Cc1ccc(O)cc1)C(=O)[O-]</smiles>

$\mathrm{Xb}$<smiles>CC1(C)OC(=O)CC(=O)O1</smiles><smiles>C1CC1</smiles>
$\mathrm{HO}$<smiles>[NH3+][C@@H](Cc1ccc(O)cc1)C(=O)O</smiles><smiles>CC1(C)OC(=O)C(=O)C(=O)O1</smiles>

XC

2<smiles></smiles><smiles>C=C([O-])[C@H](N)Cc1ccc(O)cc1</smiles><smiles>[R]c1ccc(C=O)cc1</smiles><smiles>[C]=C</smiles>
$1^{\mathrm{I}}$

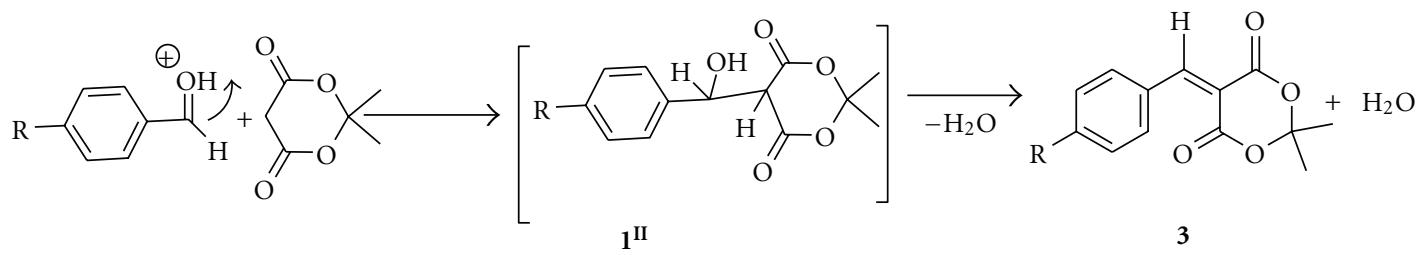

Scheme 2: Plausible mechanism for the formation of $\mathbf{3}$ from $\mathbf{1}$ and $\mathbf{2}$ in the presence of L-tyrosine under solvent-free condition at room temperature.

In summary, L-Tyrosine as an efficient catalyst for the preparation of substituted-5-benzylidene-2,2-dimethyl$[1,3]$ dioxane-4,6-dione by Knoevenagel condensation in the solvent free condition under the grind stone method at room temperature. This method is applicable to a wide range of arylaldehydes $\mathbf{1}(\mathbf{a}-\mathbf{j})$ and meldrum's acid (2) containing active methylene group to produce substituted -5benzylidene-2,2-dimethyl-[1,3] dioxane-4,6-diones $\mathbf{3}(\mathbf{a}-\mathbf{j})$ in solvent-free condition under grindstone method at room temperature.

The attractive features of this procedure are the mild reaction conditions, high conversions, operational simplicity, and inexpensive and ready availability of the catalyst, all of which make it a useful and attractive strategy for the preparation of substituted -5-benzylidene-2,2-dimethyl$[1,3]$ dioxane-4,6-dione in solvent-free condition under grindstone method at room temperature.

\section{Experimental Section}

Melting points were measured in open capillary tubes and are uncorrected. TLC was done on plates coated with silica gel-G and spotting was done using iodine or UV lamp. IRspectra were recorded using FT-IR in $\mathrm{KBr}$ phase. ${ }^{1} \mathrm{H}-\mathrm{NMR}$ spectra were recorded at $400 \mathrm{MHz}$, respectively. Compounds are known, and products were identified by spectral and melting-point comparison with the authentic samples.

General Procedure for the Preparation of $\mathbf{3}(\boldsymbol{a}-\mathbf{j})$ from $\mathbf{1}(\boldsymbol{a}-\mathbf{j})$ and Meldrum's Acid. A mixture of 1 (10 mmol), meldrum's acid $2(10 \mathrm{mmol})$, and L-tyrosine $(2 \mathrm{mmol})$ was physically grinded in solvent-free condition under grindstone method at room temperature for a specified period of time (Table 1). After completion of reaction (as shown by TLC checking), the mixture was poured into ice-cold water $(50 \mathrm{~mL})$. The separated solid was filtered, washed with water $(100 \mathrm{~mL})$, and dried to obtain crude $\mathbf{3}(\mathbf{a}-\mathbf{j})$. The latter were then recrystallised from ethanol to afford pure $\mathbf{3}(\mathbf{a}-\mathbf{j})$. Compounds are known, and products were identified by spectral and melting-point comparison with the authentic samples.

\section{Acknowledgments}

The authors are thankful to the Jawaharlal Nehru Technological University Hyderabad, India, for providing financial support and to the principal of College of Engineering, Jawaharlal Nehru Technological University Hyderabad, Kukatpally, Hyderabad, for providing laboratory facilities.

\section{References}

[1] K. Tanaka and F. Toda, "Solvent-free organic synthesis," Chemical Reviews, vol. 100, no. 3, pp. 1025-1074, 2000.

[2] K. Tanaka, Solvent-Free Organic Synthesis, Chapter 3. 2, WileyVCH, Weinheim, Germany, 2003.

[3] G. Jones, "Advanced organic chemistry: reaction mechanisms," Organic Reaction, vol. 15, pp. 204-599, 1967.

[4] E. Knoevenagel, "Dry media reaction procedure for synthessis of $\alpha, \beta$-unsaturated acids, $\alpha$-cyanoacrylonitriles and $\alpha$ cyanoacrylates via knoevenagel condensation using $\mathrm{NaHSO}_{4}$. $\mathrm{SiO}_{2}$ catalyst," Berichte, vol. 31, pp. 2585-2596, 1898. 
[5] L. F. Tietze and U. Beifuss, Comprehensive Organic Synthesis, vol. 2, Pergamon, Oxford, UK, 1991, Edited by B. M. Trost, I. Fleming, and C. H. Heathcock.

[6] F. Freeman, "Properties and reactions of ylidenemalononitriles," Chemical Reviews, vol. 80, no. 4, pp. 329-350, 1980.

[7] N. Zidar, T. Tomašić, R. Šink et al., "Discovery of novel 5-benzylidenerhodanine and 5-benzylidenethiazolidine-2, 4dione inhibitors of MurD ligase," Journal of Medicinal Chemistry, vol. 53, no. 18, pp. 6584-6594, 2010.

[8] M. A. Ibrahim, M. A. M. Abdel-Hamed, and N. M. El-Gohary, "A new approach for the synthesis of bioactive heteroaryl thiazolidine-2,4-diones," Journal of the Brazilian Chemical Society, vol. 22, no. 6, pp. 1130-1139, 2011.

[9] M. Oguchi, K. Wada, H. Honma et al., "Molecular design, synthesis, and hypoglycemic activity of a series of thiazolidine2,4-diones," Journal of Medicinal Chemistry, vol. 43, no. 16, pp. 3052-3066, 2000.

[10] M. S. Malamas, J. Sredy, I. Gunawan et al., "New azolidinediones as inhibitors of protein tyrosine phosphatase $\mathrm{lb}$ with antihyperglycemic properties," Journal of Medicinal Chemistry, vol. 43, no. 5, pp. 995-1010, 2000.

[11] R. Murugan, S. Anbazhagan, and S. Sriman Narayanan, "Synthesis and in vivo antidiabetic activity of novel dispiropyrrolidines through $[3+2]$ cycloaddition reactions with thiazolidinedione and rhodanine derivatives," European Journal of Medicinal Chemistry, vol. 44, no. 8, pp. 3272-3279, 2009.

[12] U. V. Desai, D. M. Pore, R. B. Mane, S. B. Solabannavar, and P. P. Wadgaonkar, "One pot synthesis of monoalkylated and mixed, dialkylated meldrum's acid derivatives," Synthetic Communications, vol. 34, no. 1, pp. 25-32, 2004.

[13] D. Fildes, V. Caignaert, D. Villemin, and P. A. Jaffrès, "Potassium exchanged zirconium hydrogen phosphate $\mathrm{Zr}\left(\mathrm{O}_{3} \mathrm{POK}\right)_{2}$ : a heterogeneous basic catalyst for Knoevenagel reaction without solvent," Green Chemistry, vol. 3, no. 1, pp. 52-56, 2001.

[14] F. Texier-Boullet and A. Foucaud, "Knoevenagel condensation catalysed by aluminium oxide," Tetrahedron Letters, vol. 23, no. 47, pp. 4927-4928, 1982.

[15] J. A. Cabello, J. M. Campelo, A. Garcia, D. Luna, and J. M. Marinas, "Knoevenagel condensation in the heterogeneous phase using $\mathrm{AlPO}_{4}-\mathrm{Al}_{2} \mathrm{O}_{3}$ as a new catalyst," Journal of Organic Chemistry, vol. 49, no. 26, pp. 5195-5197, 1984.

[16] J. S. Yadav, B. V. Subba Reddy, A. K. Basak, B. Visali, A. V. Narsaiah, and K. Nagaiah, "Phosphane-catalyzed knoevenagel condensation: a facile synthesis of $\alpha$-cyanoacrylates and $\alpha$ cyanoacrylonitriles," European Journal of Organic Chemistry, no. 3, pp. 546-551, 2004.

[17] D. H. Yang, B. Y. Yang, Z. C. Chen, and S. Y. Chen, "A convenient synthesis of 5-arylidenethiazolidine-2,4-diones on potassium fluoride-aluminium oxide," Organic Preparations and Procedures International, vol. 38, no. 1, pp. 81-85, 2006.

[18] D. Prajapati, K. C. Lekhok, J. S. Sandhu, and A. C. Ghosh, "Magnesium per chlorate as efficient lewis acid for the knoevenagel condensation between $\beta$-diketones and aldehydes," Journal of the Chemical Society, Perkin Transactions, vol. 1, p. 959, 1996.

[19] P. Shantan Rao and R. V. Venkataratnam, "Zinc chloride as a new catalyst for Knoevenagel condensation," Tetrahedron Letters, vol. 32, no. 41, pp. 5821-5822, 1991.

[20] A. V. Narsaiah and K. Nagaiah, "An efficient knoevenagel condensation catalyzed by $\mathrm{LaCl}_{3} .7 \mathrm{H}_{2} \mathrm{O}$ in heterogeneous medium," Synthetic Communications, vol. 33, no. 21, pp. 3825-3832, 2003.
[21] L. Martins, K. M. Vieira, L. M. Rios, and D. Cardoso, "Basic catalyzed Knoevenagel condensation by FAU zeolites exchanged with alkylammonium cations," Catalysis Today, vol. 133-135, no. 1-4, pp. 706-710, 2008.

[22] U. P. N. Tran, K. K. A. Le, and N. T. S. Phan, "Expanding applications of metal-organic frameworks: zeolite imidazolate framework zif- 8 as an efficient heterogeneous catalyst for the knoevenagel reaction," ACS Catalysis, vol. 1, no. 2, pp. 120$127,2011$.

[23] T. I. Reddy and R. S. Varma, "Rare-earth (RE) exchanged NaY zeolite promoted Knoevenagel condensation," Tetrahedron Letters, vol. 38, no. 10, pp. 1721-1724, 1997.

[24] Y. Hu, Z. C. Chen, Z. G. Le, and Q. G. Zheng, "Organic reactions in ionic liquids: gewald synthesis of 2-aminothiophenes catalyzed by ethylenediammonium diacetate," Synthetic Communications, vol. 34, no. 20, pp. 3801-3806, 2004.

[25] P. Formentín, H. García, and A. Leyva, "Assessment of the suitability of imidazolium ionic liquids as reaction medium for base-catalysed reactions: case of Knoevenagel and ClaisenSchmidt reactions," Journal of Molecular Catalysis A, vol. 214, no. 1, pp. 137-142, 2004.

[26] Y. Hu, Z. C. Chen, Z. G. Le, and Q. G. Zheng, "Organic reactions in ionic liquids: gewald synthesis of 2-aminothiophenes catalyzed by ethylenediammonium diacetate," Synthetic Communications, vol. 34, no. 20, pp. 3801-3806, 2004.

[27] F. Santamarta, P. Verdía, and E. Tojo, "A simple, efficient and green procedure for Knoevenagel reaction in $[\mathrm{MMIm}]\left[\mathrm{MSO}_{4}\right]$ ionic liquid," Catalysis Communications, vol. 9, no. 8, pp. 1779-1781, 2008.

[28] H. McNab, "Meldrum's acid," Chemical Society Reviews, vol. 7, no. 3, pp. 345-358, 1978.

[29] G. A. Kraus and M. E. Krolski, "Synthesis of a precursor to quassimarin," Journal of Organic Chemistry, vol. 51, no. 17, pp. 3347-3350, 1986.

[30] X. Huang and L. Xie, "One-pot synthesis of mono substituted isopropylidene malonates," Synthetic Communications, vol. 16, pp. 1701-1707, 1986.

[31] A. J. Kadam, U. V. Desai, and R. B. Mane, "Synthesis of deuterium labelled acids," Journal of Labelled Compounds and Radio Pharmaceuticals, vol. 42, pp. 835-842, 1999.

[32] R. C. F. Brown, F. W. Eastwood, and K. J. Harrington, "Methyleneketenes and methylenecarbenes: formation of arylmethyleneketenes and alkylideneketenes by pyrolysis of substituted 2, 2-dimethyl-1, 3-dioxan-4, 6-diones," Australian Journal of Chemistry, vol. 27, pp. 2373-2384, 1974.

[33] R. C. F. Brown and G. L. McMullen, "Methyleneketenes and methylenecarbenes: a new phenolic ring synthesis: 2-naphthol from o-tolualdehyde," Australian Journal of Chemistry, vol. 27, pp. 2385-2391, 1974.

[34] S. Nakamura, H. Hirao, and T. Ohwada, "Rationale for the acidity of Meldrum's acid. Consistent relation of C-H acidities to the properties of localized reactive orbital," Journal of Organic Chemistry, vol. 69, no. 13, pp. 4309-4316, 2004.

[35] M. T. Thorat, M. H. Jagdale, R. B. Mane, M. M. Salunkhe, and P. P. Wadgaonkar, "Clay-catalysed knoevenagel condensation," Current Science, vol. 56, pp. 771-772, 1987.

[36] P. S. Rao and R. V. Venkataratnam, "Anhydrous zinc chloride catalysis in carbonyl-methylene condensations: synthesis of arylidene acetonitriles and arylidene heterocycles," Indian Journal of Chemistry B, vol. 32, pp. 484-486, 1993.

[37] M. Venkatanarayana and P. K. Dubey, "L-proline-catalyzed knoevenagel condensation: a facile, green synthesis of (e)-ethyl -2-cyano-3-(1H-indol-3-yl)acrylates and (e)-3-(1H-indol-3yl)acrylonitriles," Synthetic Communications, vol. 42, pp. 1746-1759, 2012. 


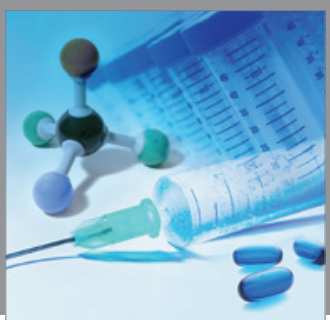

International Journal of

Medicinal Chemistry

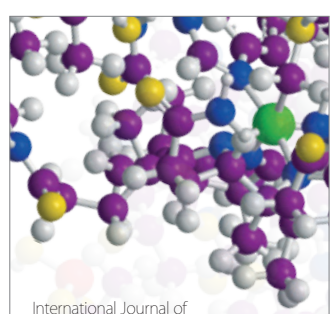

Carbohydrate Chemistry

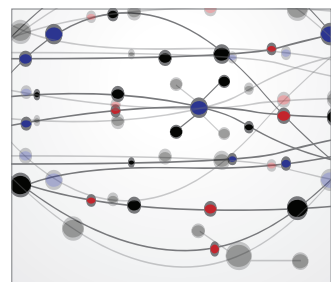

The Scientific World Journal
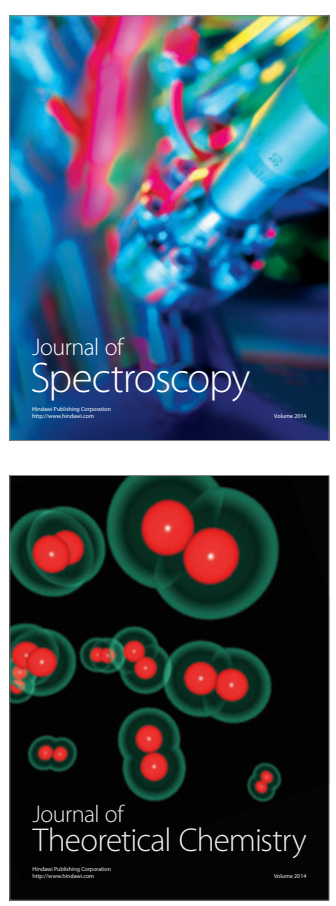
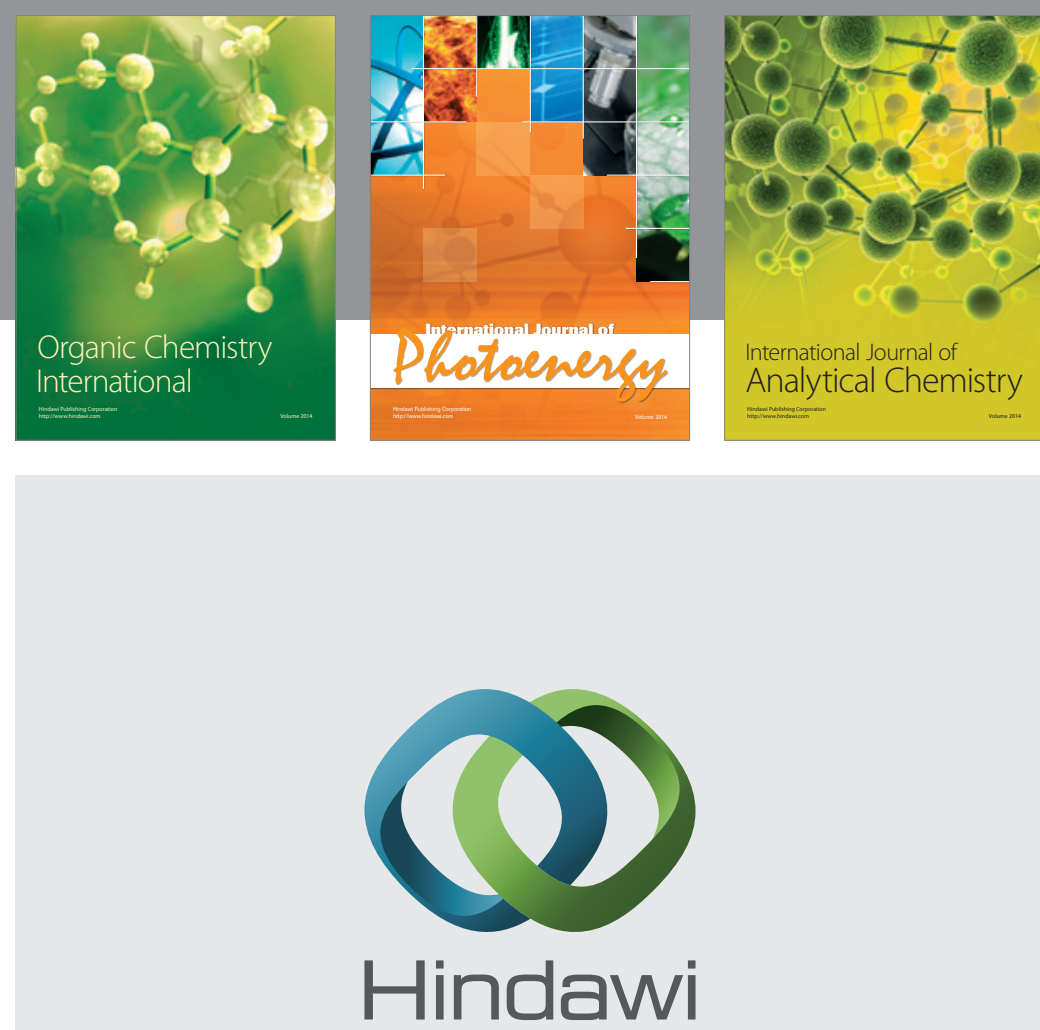

Submit your manuscripts at

http://www.hindawi.com
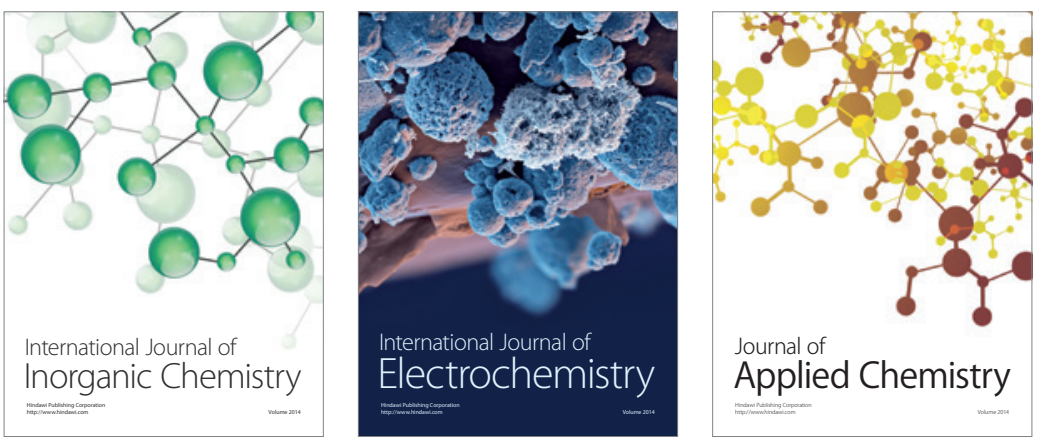

Journal of

Applied Chemistry
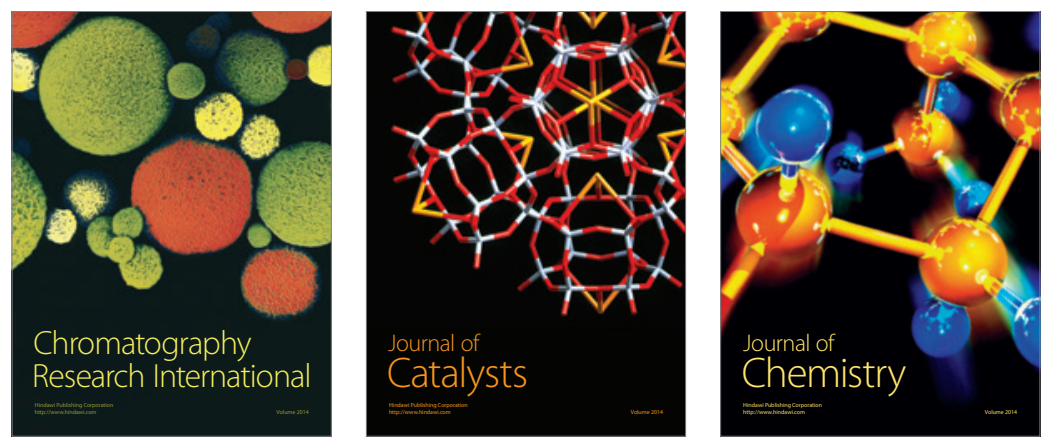
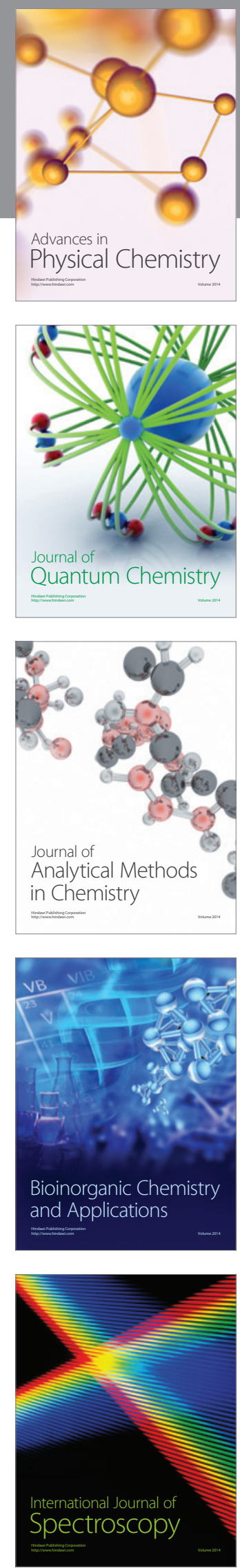